\author{
N.F. Abayeva ${ }^{1}$, I.I. Yerakhtina ${ }^{1}$, M. Mustafina ${ }^{1}$, S.G. Kurymbayev ${ }^{2}$ \\ ${ }^{1}$ Karaganda State Technical University, Kazakhstan; \\ ${ }^{2}$ Ye.A. BuketovKaraganda State University, Kazakhstan \\ (E-mail: a_nella@mail.ru)
}

\title{
Currently topical problems of teaching mathematics at the Technical University
}

\begin{abstract}
This article considers the issue of higher professional education improvement in Kazakhstan, on the example of «Mathematics» discipline teaching for university students enrolled in «Biotechnology» and «Chemical technology of organic substances» specialties. Through mathematics course professional orientation to students future professional activities, to increase students' level of academic performance and to arouse interest in mathematics study, laying the foundation for scientific activity of applying mathematical methods in biotechnology. In the article there was conducted the analysis to identify the differences in volume of mathematical disciplines studied in the Republic of Kazakhstan, 4 universities were considered; 10 universities in the Russian Federation; 2 universities in the Republic of Belarus. The authors analyzed the content of textbooks, manuals and topics for compliance with the standard curriculum for considered specialties. The article presents ways to solve the problem for «Improving mathematical training quality». There are presented the results of students' training on the professionally-oriented program designed by the authors, which allowed to increase mathematical knowledge level. The authors consider the issue of the discrepancy between the number of allocated hours for mathematical disciplines study in the Republic of Kazakhstan and other countries of near and far abroad, which results in the problems of two diploma educations.
\end{abstract}

Key words: mathematics, teaching, mathematical methods, mathematical preparation, vocational guidance, interest, cognitive interest, vocational education, specialty, quality improvement.

\section{Introduction}

On 23 January 2019 at the opening ceremony of the Year of Youth N.A. Nazarbayev said: «Investments in human capital are the most profitable country's investments. In the Young Literacy Index, Kazakhstan ranks 15 th place among 155 countries of the world. In terms of youth education, our country takes 9-th place, ahead of Switzerland, the USA, Norway and Finland.

Kazakhstan can become a «new intellectual empire».

Taking into consideration that our country is preparing for a more advanced technological and digital future, it is extremely important to keep up with the latest trends in the field of education.

Kazakhstan should provide the youth with required knowledge and skills that will ensure success and prosperity for everybody $[1 ; 2]$.

On 5 September 2012 in the lecture given to the students of Nazarbayev University, N.A. Nazarbayev mentioned that Kazakhstan is moving towards a post-industrial world where the triad rules «education science - innovations» [2;1]. In this regard, one of the most important factors is to increase the level of today's youth education, who in near future will have to develop Kazakhstani science, and the sooner we start to introduce elements of professional orientation into the educational process, the more deeply students will be able to understand the role of each science in their future professional activities.

Mathematics teaching in higher education has always faced with great problems: low level of preuniversity training and no desire to study mathematics, but at the root of all these problems there lies the fact that students have no desire to study mathematics, since they do not understand and do not know its place in their future professional activity. Therefore, by professional orientation of the mathematics course on Biotechnology, we can achieve the following:

- improve students' academic performance;

- teach students to use mathematical methods in Biotechnology;

- teach students to work with modern technologies, since they are all based mainly on the mathematical methods application;

- carry out scientific works at the intersection of sciences such as Biotechnology-Mathematics [3; 93891]. 


\section{Main part}

As practice shows, the role of mathematics in future biotechnology specialist training at university is unremarkable, since in all cases biological and chemical disciplines have top priority, and theoretical ones, including Mathematics, are sidelined. This is due to the fact that the university's educational process does not take into account the rapid biotechnology mathematization based on the fact that new technologies and methods based on mathematical achievements in Biotechnology are being introduced $[4 ; 12]$. It results in misunderstanding and careless attitude to mathematics study by students. Thus, students underestimate the role of Mathematics in their future professional activities.

Vast experience has been accumulated in various fields of pedagogical science in Kazakhstan on problem of vocational education improvement: works devoted to technical education: B.A. Abdikarimov, A.M. Abdirov, T.T. Galiev; works devoted to vocational education improvement in higher education schools: G.Z. Abilgazinov, V.V. Egorov, G.D. Zhangizina, N.A. Zavalko, G.K. Nurtaeva. Nevertheless, the problem of Biotechnological vocational education and its psychological and pedagogical aspects are not sufficiently developed and are not given due attention.

Students' negative attitude to Mathematics study is aggravated by low initial level of school knowledge. The carried out analysis made it possible to identify the level of students' pre-university mathematical knowledge enrolled in a higher education institution, that is, the average unified national test (UNT) score is 13.1 out of 25 possible, which is $52.4 \%$, which certainly affects mathematics future study in high school.

In the modern world, mathematics is increasingly being introduced into chemical practice - mathematical analysis is becoming an essential tool of chemical science and technology. Advanced mathematics use to solve chemical and chemical-technological tasks leads to valuable results, the obtaining of which in other ways can be difficult or impossible. At all stages of design and management of chemical-technological processes, mathematical models are used, adequacy and informativeness of which depends on research depth of physicochemical regularities processes and functional relationships among their parameters [5; 52].

So, let us consider mathematical methods used in Chemistry and Chemical technology, in particular:

1. Theory of graphs. This use makes it possible to predict chemical transformations, explain essence and systematize some basic concepts of Chemistry: structure, configuration, conformations, quantummechanical and statistical-mechanical interaction of molecules, isomerism.

2. Topology is used in stereochemistry and it allows to explore potential energy surfaces properties.

3. Knot theory. Knots formed by polymer chains are studied.

4. Combinatorics is used to study spiral relationship and interdependence in periodic table of chemical elements.

5. Groups theory is used to classify crystal lattices and molecules symmetries.

6. Fractal geometry helps to study fractal systems in Chemistry, dendrimers are a prime example.

7. Differential equations are widely used in Chemical kinetics.

8. Dynamic systems theory is used to study dynamic systems in Chemistry.

9. Catastrophes and bifurcations theory is used to describe molecules structural changes.

10. Operator algebra is used in quantum mechanics.

11. Mathematical logic is used to study chemical transformations and molecular logic.

12. Information theory and artificial intelligence methods are used in Chemoinformatics

13. Integral differential equations theory helps to study processes on non-uniform surfaces.

The upcoming trend of Modern chemistry is mathematical planning of experiment, which can be considered as one of the sections of mathematical modeling. For Bioorganic and Pharmaceutical Chemistry, study of physiological activity dependence on structure, is a very important problem. The mathematical calculations use can significantly improve chemist-synthetic's performance.

From all discussed above it follows that Chemistry development is impossible without the mathematical methods use in it.

Thus, mathematical methods use in Biotechnology is quite wide and when giving lectures and conducting practical exercises, we demonstrate to students the importance of a separate topic in their future professional activity. This implementation made it possible to arouse interest in Mathematics study, since we put the following into the basis of Mathematics teaching: Mathematics is necessary for technical students as a tool for deeper and more complete mastering of special disciplines, which in turn will allow to become a highly qualified specialist in their field in the future (Fig. 1.) [6; 104]. 


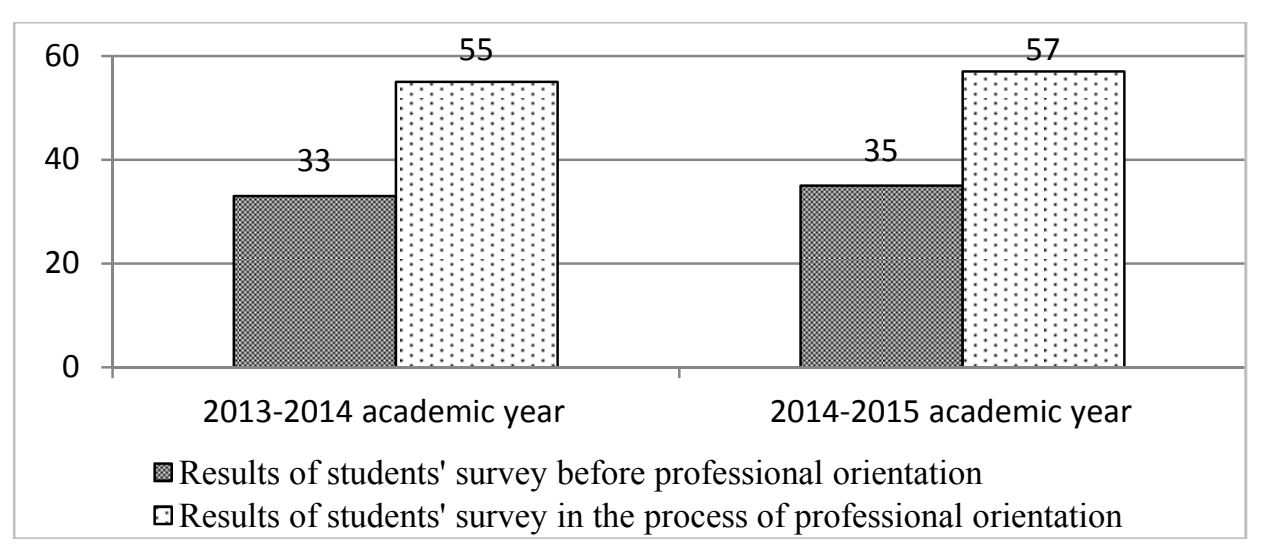

Figure 1. Results of students' survey

Models are objects of study in Mathematics. In these models, Mathematics studies correlations between elements, quantitative and qualitative, links between them, and their forms. The same mathematical model can describe properties of very distant from each other by their specific content real phenomena with a certain approximation. Mathematics abstraction gives it power, universalism and community. Mathematics provides powerful methods for world understanding, as well as for studying its laws. Mathematical models allow to analyze the results of practical activity with a sufficient degree of reliability. The history of the natural science development convincingly testifies to high efficiency of natural sciences mathematization [7; 25]. A quantitative mathematical description raises science to a higher level, deepens processes understanding, and sometimes is the only way to link into a single, coherent picture the effect of numerous interrelated and sometimes quite diverse factors peculiar to the phenomena under consideration. Therefore, it is necessary for us, mathematical disciplines teachers at university, to arouse students' interest in studying advanced mathematics course by demonstrating them the field of mathematical knowledge application in their future professional activity. But in educational process we have to deal with negative attitude bordering on rejection, and the reason is due to the low level of basic knowledge, students are afraid of this science and cannot realize its importance in their future professional activity. The teacher's task is not only to arouse interest in Mathematics studying by various pedagogical methods, but also to teach students to use mathematical apparatus as a tool to become a highly qualified specialist in their field [8; 7].

To achieve this goal, we introduced the following into educational process of Karaganda State Technical University for «Biotechnology» specialty:

- course of lectures for specific purposes;

- at practical classes we solve not only mathematical tasks, but also, for example, problems of the following content we solve not only purely mathematical problems, but also, for example, tasks of the following content:

Task 1. Consider a differential population model that is connected with reproduction or extinction. Let $x(t)$ - is the number of individuals in population at moment $t$. Then if $A$ is a number of individuals in population born per a unit of time, and $B$ is a number of dying individuals per a unit of time, then with good reason it can be argued that the rate of change $x$ with time is determined by the formula

$$
\frac{d x}{d t}=A-B \text {. }
$$

The task is to describe the correspondence of $A$ and $B$ from $x$. Let analyze the situation when

$$
A=a x, B=b x \text {, }
$$

where $a$ and $b$ are indexes of individuals' birth and death per a unit of time respectively. Taking into account equality (2) differential equation (1) will be presented as following

$$
\frac{d x}{d t}=(a-b) x .
$$

Considering that at the moment in time $t=t_{0}$ is a number of individuals in population is $x=x_{0}$ from the equation (3) we define

$$
x(t)=x_{0} e^{(a-b)\left(t-t_{0}\right)} .
$$


From the equality it follows that if $a>b$, so when $t \rightarrow \infty$ number of individuals $x \rightarrow \infty$. On the other hand, if $a<b$, so $x \rightarrow 0$ when $t \rightarrow \infty$ and population is becoming extinct [9; 47].

Task 2. The rate of bacteria reproduction is proportional to their number. At the initial moment of time $t=0$ there were 100 bacteria, and within 3 hours their number doubled. To calculate proportion of bacteria number to time. How many times will increase the bacteria number during 9 hours?

Let assume that $x$ is a number of bacteria at the moment. Then, according to the task, differential equation of the task takes is the following:

$$
\frac{d x}{d t}=k x
$$

where $k$ - proportionality coefficient. Let separate variables and integrate, as a result we get:

$$
x=C e^{k t} .
$$

To determine $C$ we use initial condition: where $t=0 \quad x=100$.

We have:

and so

$$
C=100
$$

$$
x=100 e^{k t} .
$$

Proportionality coefficient $k$ we determine from additional condition: where $t=3 x=200$.

We have:

and, therefore,

$$
200=100 e^{3 k} \text { or } 2=e^{3 k}
$$

So the required function is

$$
e^{k}=2^{\frac{1}{3}}
$$

it follows that when $t=9$

$$
x=100 \cdot 2^{\frac{t}{3}}
$$

$$
x=800 \text {. }
$$

It follows that, for 9 hours the number of bacteria increases 8 times.

- for students' independent work we select tasks with professional orientation, for example:

Task 1. Find the growth rate of bacteria population, if the growth of bacteria number of a certain population obeys the law: $f(t)=\frac{1000 e^{t}}{1+0,1\left(e^{t}-1\right)}$.

Task 2. Under favorable conditions, an increase in bacteria number over time occurs according to exponential law, mathematical model of this law is: $n(t)=C e^{k t}$, where $\mathrm{t}$ - time, $\mathrm{k}$ - proportionality coefficient. Determine the rate of bacteria number over time.

Task 3. The decomposition of chemical proceeds according to the equation: $m=m_{0} e^{-k t}$, where $\mathrm{m}-$ substance amount at the moment of time $\mathrm{t}, \mathrm{k}$ - positive constant. Determine decomposition rate of the substance and express it as a function of $\mathrm{m}$.

Task 4. Proportion of substance amount $Q$, obtained in chemical reaction from time $\mathrm{t}$ is determined by formula: $Q=a\left(1+b e^{-k t}\right)$. Determine speed reaction $v$ and express it as a function of $Q$.

- at final examination, examination cards contain tasks and question of specific purposes.

Of course, such a professionally-oriented activity requires teacher's high qualification not only as a mathematician, but as a teacher, because training is time consuming, and it requires revision of all students' learning material for vocational guidance purposes.

The similar situation is among students of «Chemical technology of organic substances» specialty, mathematics is studied in the amount of 3 credits, which is not enough for students of this profile. In order to identify the problem of non-compliance of mathematical disciplines hours, an analysis of educational programs for the designated specialties was conducted in various universities of the Republic of Kazakhstan, the Russian Federation and the Republic of Belarus (Table 1). 


\section{Summary table of mathematical disciplines hours for «Biotechnology» and «Chemical technology of organic substances» disciplines}

\begin{tabular}{|c|c|c|c|c|}
\hline \multirow{2}{*}{ № } & \multirow{2}{*}{ Country } & \multirow{2}{*}{ Name of university } & \multicolumn{2}{|c|}{$\begin{array}{l}\text { Total volume of studied } \\
\text { mathematical disciplines }\end{array}$} \\
\hline & & & Biotechnology & $\begin{array}{l}\text { Chemical technology } \\
\text { of organic substances }\end{array}$ \\
\hline 1 & \multirow{4}{*}{$\begin{array}{l}\text { The Republic } \\
\text { of Kazakhstan }\end{array}$} & Sh. Ualikhanov Kokshetau state university & 135 & - \\
\hline 2 & & Karaganda state technical university & 135 & 180 \\
\hline 3 & & M.H. Dulati Taraz state university & 135 & 180 \\
\hline 4 & & S. Seifullin Kazakh AgroTechnical university & 135 & - \\
\hline 5 & \multirow{10}{*}{$\begin{array}{l}\text { The Russian } \\
\text { Federation }\end{array}$} & Moscow state university of food production & 108 & - \\
\hline 6 & & $\begin{array}{l}\text { Ivanovo state university of chemistry and } \\
\text { technology }\end{array}$ & 578 & 578 \\
\hline 7 & & Ufa state oil technical university & - & 432 \\
\hline 8 & & Vyatsk state university & 108 & 324 \\
\hline 9 & & $\begin{array}{l}\text { N.G. Chernishevsliy National research Sara- } \\
\text { tov state university }\end{array}$ & - & 288 \\
\hline 10 & & Russian state university of oil and gas & 216 & 432 \\
\hline 11 & & Tomsk polytechnic university & 108 & 432 \\
\hline 12 & & Kaliningrad state technical university & 273 & - \\
\hline 13 & & Tyumen oil-gas state university & - & 578 \\
\hline 14 & & Novosibirsk state technical university & 468 & - \\
\hline 15 & $\begin{array}{l}\text { The Republic of } \\
\text { Mordovia (part } \\
\text { of the Russian } \\
\text { Federation) }\end{array}$ & $\begin{array}{l}\text { Ogarev National research Mordova state uni- } \\
\text { versity }\end{array}$ & 180 & - \\
\hline \multirow{2}{*}{$\frac{16}{17}$} & \multirow{2}{*}{$\begin{array}{l}\text { The Republic } \\
\text { of Belarus }\end{array}$} & Belarus state university & 234 & 658 \\
\hline & & Brest state university & 234 & 658 \\
\hline
\end{tabular}

From the above data it is clear that there is rather large difference in the volume of hours in these specialties. Therefore, it is rather difficult for students of these specialties to study in two-degree programs in other countries. In universities of far abroad-countries, hours spent on studying mathematical disciplines are much more than in universities of the Republic of Kazakhstan, Russia, and the Republic of Belarus. Mathematical disciplines studying in all universities presented in the analysis is a compulsory basic component, and abroad, these are optional disciplines, as students of these specialties understand that they need to master their basic mathematical apparatus for further successful professional activity.

In universities of the Republic of Kazakhstan, it is necessary to develop students' interest in mathematical disciplines study, and then students will be able to understand why they need to study mathematics and will choose math courses among «optional» disciplines, which in its turn will lead to their being more mobile in school, process of two-degree program education. And the development of students' interest in mathematics study, we see through - professional-oriented learning. We also analyzed the content of textbooks, manuals and topics corresponding to the standard curriculum, thus we came to the following conclusion: none of the existing textbooks and manuals meets the modern requirements of the SES RK and standard curriculum. The absence of such a textbook or manual creates certain difficulties in teaching mathematics and affects the quality of its study. Mathematical education issues of technical university students need to be solved as rapidly as possible, since mathematical training is a component of basic general higher education, the purpose of which is students' intellectual education, thinking development, cognitive abilities development.

In order to successfully apply mathematical methods in specialist's further professional activity, to simulate various chemical and biological processes and technologies, first of all, you need to have necessary knowledge and be able to properly handle mathematical apparatus, know Geometry - for geometric analysis of living forms; lines, planes and surfaces - to describe forms of molecular bonds, spatial models of DNA, membrane structures; rate of enzymatic reactions in tissues and biological fluids is linear, it can natu- 
rally be described by linear algebraic expressions. To record research conducted and results obtained, there is used language of numbers, various mathematical symbols, formulas and logical descriptions. All this must be learned by students in their first year as a result of mathematics discipline studying.

\title{
Conclusions
}

Thus, despite all the difficulties, this technology of vocational-oriented learning has been introduced in KSTU since 2015. As a result, we can ascertain at this stage the annual increase in student performance, an average of $9 \%$.

The students' interest can also be characterized by the following, at annual student scientific conferences held by Karaganda State Technical University in 2015-2019 on the topic «The contribution of youth science in implementation of Strategy» Kazakhstan-2050», the largest number of participating students was in the section of «Applied Mathematics», of specialties «Biotechnology» and «Chemical Technology of Organic Substances». They are interested in doing scientific research at junction of mathematics and biotechnology and chemical technology. And we are confident that it is these students starting from the first year, are engaged in scientific activities to the best of their abilities, in future will be able to put into practice the words of our President «education — science — innovation».

\section{References}

1 Выступление Президента Казахстана Н.А. Назарбаева на торжественной церемонии открытия Года молодежи (23 января 2019 г.). — Нурсултан [Электронный pecypc]. — Режим доступа: http://www.akorda.kz/ru /speeches/internal_political_affairs/in_speeches_and_addresses/vystuplenie-prezidenta-kazahstana-na-nazarbaeva-na-torzhestvennoiceremonii-otkrytiya-goda-molodezhi

2 Выступление Президента Казахстана Н.А. Назарбаева перед студентами Назарбаев Университета «Казахстан на пути к обществу знаний» (5 сентября 2012 года) [Электронный ресурс]. - Астана — Режим доступа: http://www.zakon.kz/4511854-strana-dvizhetsja-k-postindustrialnomu.html

3 Abayeva N.F. About Professional Orientation of the Mathematics as a Discipline for Students Majoring in Biotechnology / N.F. Abayeva, V.V. Yegorov, V.N. Golovachyova, L.M. Mustafina, I.I. Yerakhtina, B.M. Mustafina // Indian journal of science and technology. - 2016. - 9(19) - P. 93-99.

4 Егоров В.В. О некоторых путях развития познавательного интереса студентов медицинских вузов к математике / В.В. Егоров, В.Н. Головачева, Н.Ф. Абаева // Вестн. Караганд. ун-та. Сер. Педагогика. — 2005. — № 3(39). — С. 11-19.

5 Абаева Н.Ф. Профессиональная ориентация математики как фактор повышения качества знаний / Н.Ф. Абаева, Л.М. Мустафина // Вестн. Академии педагогических наук Казахстана. — 2014. — № 6. — С. 50-57.

6 Абаева Н.Ф. Формирование познавательного интереса к математике у студентов вуза / Н.Ф. Абаева. — Караганда: Изд-во КарГТУ, 2015. - 188 с.

7 Shegirova D.K. Realization of active teaching methods in mathematics lessons / D.K. Shegirova, D.A. Zhumagul, N.B. Mikhailova // Bulletin of the Karaganda University «Pedagogy» series. — 2018. — № 3(91). — P. $23-29$.

8 Головачева В.Н. К вопросу о качестве математической подготовки студентов технического вуза / В.Н. Головачева, Н.Ф. Абаева, М.М. Коккоз // Труды университета. — 2015. — № 2. - С. 5-8.

9 Abayeva N.F. The Fourth International Conference on Eurasian scientific development: Proceedings of the Conference (March 1, 2015). - Vienna: «East West» Association for Advanced Studies and Higher Education, 2015. - P. 45-49.

\section{Н.Ф. Абаева, И.И. Ерахтина, Л.М. Мұстафина, С.Г. Курымбаев \\ Техникалық жоғарғы оқу орнында математиканы оқытудың өзекті мәселелері}

\begin{abstract}
Мақалада «Органикалық заттардың химиялық технологиясы» және «Биотехнология» мамандығында оқитын жоо студенттеріне «Математика» пәнін оқыту мысалында жоғары кәсіби білім беруді жетілдірудің сұрақтары қарастырылған. Авторлар математика курсын студенттердің болашақ ісәрекетіне кәсіби бағдарлай отырып, биотехнологияда математикалық әдістерді қолданудың ғылыми іс-әрекетінің негізін қалап, студенттердің жетістік деңгейлерін арыттыруға және математиканы оқуға деген қызығушылықты оятуға болады деп санайды. Қазақстан Республикасында оқытылатын математикалық пәндер көлеміндегі айырмашылықтарды анықтау үшін талдау жүргізілді. Ресей Федерациясының - 10, Беларусь Республикасының — 2, Қазақстан Республикасының - 4 жоғары оку орны қарастырылды. Ұсынылған мамандықтар бойынша типтік бағдарламаның оқу бағдарламасына сәйкестігі үшін окулықтардың, оқу-әдістемелік құралдардың және тақырыптардың мазмұны талданды. Мақалада «Математикалық оқытудың сапасын арттыру» мәселесін шешу жолдары баяндалған. Математикалық білім деңгейін көтеруге мүмкіндік беретін авторлар әзірлеген
\end{abstract}


кәсіптік-бағдарланған бағдарлама бойынша студенттерді оқыту нәтижелері ұсынылды. Мақала авторлары Қазақстан Республикасында және жақын және алыс шетелдерде математикалық пәндерді окуға бөлінген сағаттар санының сәйкес келмеуін салыстырды және анықтады; бұл өз кезегінде қос дипломды білім беру мәселелеріне әкеледі.

Кілт сөздер: математика, оқыту, математикалық әдістер, математикалық даярлық, кәсіби бағдар беру, қызығушылық, танымдық қызығушылық, кәсіптік білім беру, мамандық, біліктілікті арттыру.

\section{Н.Ф. Абаева, И.И. Ерахтина, Л.М. Мустафина, С.Г. Курымбаев}

\section{Актуальные проблемы преподавания математики в техническом вузе}

В статье рассмотрен вопрос о совершенствовании высшего профессионального образования в Казахстане, на примере преподавания дисциплины «Математика» у студентов вуза, обучающихся на специальности «Биотехнология» и «Химическая технология органических веществ». Авторы считают, что путем профессиональной ориентации курса математики на будущую деятельность студентов можно повысить уровень успеваемости студентов и возбудить интерес к изучению математики, заложив основы научной деятельности применения математических методов в биотехнологии. Проведен анализ на выявление разницы в объеме изучаемых математических дисциплин в Республике Казахстан. Рассмотрено 4 вуза в Республике Казахстан, в Российской Федерации - 10, в Республике Беларусь - 2 вуза. Проанализированы содержания учебников, учебных пособий и тем на соответствие учебной типовой программе для представленных специальностей. Авторами приведены конкретные пути решения проблемы «Повышение качества математической подготовки». Представлены результаты обучения студентов по разработанной профессионально-ориентированной программе, которая позволила повысить уровень математических знаний. Авторы статьи сравнили и выявили несоответствие количества выделяемых часов на изучение математических дисциплин в Республике Казахстан и других странах ближнего и дальнего зарубежья, что, в свою очередь, приводит к проблемам двудипломного образования.

Ключевые слова: математика, преподавание, математические методы, математическая подготовка, профессиональная ориентация, интерес, познавательный интерес, профессиональное образование, специальность, повышение качества.

\section{References}

1 Vystuplenie Prezidenta Kazakhstana N.A. Nazarbaeva na torzhestvennoi tseremonii otkrytiia Hoda molodezhi (23 yanvaria 2019 hoda) [Speech of the President of Kazakhstan N.A. Nazarbayev at the opening ceremony of the year of youth]. akorda.kz. Retrieved from http://www.akorda.kz/ru/speeches/internal_political_affairs/in_speeches_and_addresses/vystuplenie-prezidentakazahstana-na-nazarbaeva-na-torzhestvennoi-ceremonii-otkrytiya-goda-molodezhi [in Russian].

2 Vystuplenie Prezidenta Kazakhstana N.A. Nazarbaeva pered studentami Nazarbaev Universiteta «Kazakhstan na puti k obshchestvu znanii» (5 sentiabria 2012 hoda) [Speech of the President of Kazakhstan N.A. Nazarbayev to the students of Nazarbayev University «Kazakhstan on the way to the knowledge society»]. zakon.kz. Retrieved from http://www.zakon.kz/4511854-stranadvizhetsja-k-postindustrialnomu.html [in Russian].

3 Abayeva, N.F., Yegorov, V.V., Golovachyova, V.N., Mustafina, L.M., Yerakhtina, I.I., \& Mustafina, B.M. (2016). About Professional Orientation of the Mathematics as a Discipline for Students Majoring in Biotechnology. Indian journal of science and technology, 9 (19), 93-99.

4 Egorov V.V., Golovacheva V.N., \& Abaeva N.F. (2005) O nekotorykh putiakh razvitiia poznavatelnoho interesa studentov meditsinskikh vuzov $\mathrm{k}$ matematike [About some ways of development of cognitive interest of medical students to mathematics]. Vestnik Karahandinskoho universiteta. Seriia Pedahohika - Bulletin of the Karaganda University. Pedagogy Series, 3(39), 11-19 [in Russian].

5 Abaeva, N.F., \& Mustafina, L.M. (2014). Professionalnaia orientatsiia matematiki kak faktor povysheniia kachestva znanii [Professional orientation of mathematics as a factor of improving the quality of knowledge]. Vestnik Akademii pedahohicheskikh nauk Kazakhstana - Bulletin of the Academy of pedagogical Sciences of Kazakhstan, 6, 50-57 [in Russian].

6 Abaeva, N.F. (2015). Formirovanie poznavatelnoho interesa $k$ matematike u studentov vuza [Formation of cognitive interest in mathematics among University students]. Karaganda: KarHTU [in Russian].

7 Shegirova, D.K., Zhumagul, D.A., \& Mikhailova, N.B. (2018). Realization of active teaching methods in mathematics lessons. Bulletin of the Karaganda University. Pedagogy Series, 3(91), 23-29.

8 Golovacheva, V.N., Abaeva, N.F., \& Kokkoz, M.M. (2015). K voprosu o kachestve matematicheskoi podhotovki studentov tekhnicheskoho vuza [On the question of the quality of mathematical training of students of technical University]. Trudy universiteta - Proceedings of the University, 2, 5-8 [in Russian].

9 Abayeva, N.F., Golovachyova, V.N., \& Kokkoz, M.M. (2015). The Fourth International Conference on Eurasian scientific development: Proceed-ings of the Conference (March 1, 2015). Vienna: «East West» Association for Advanced Studies and Higher Education. 